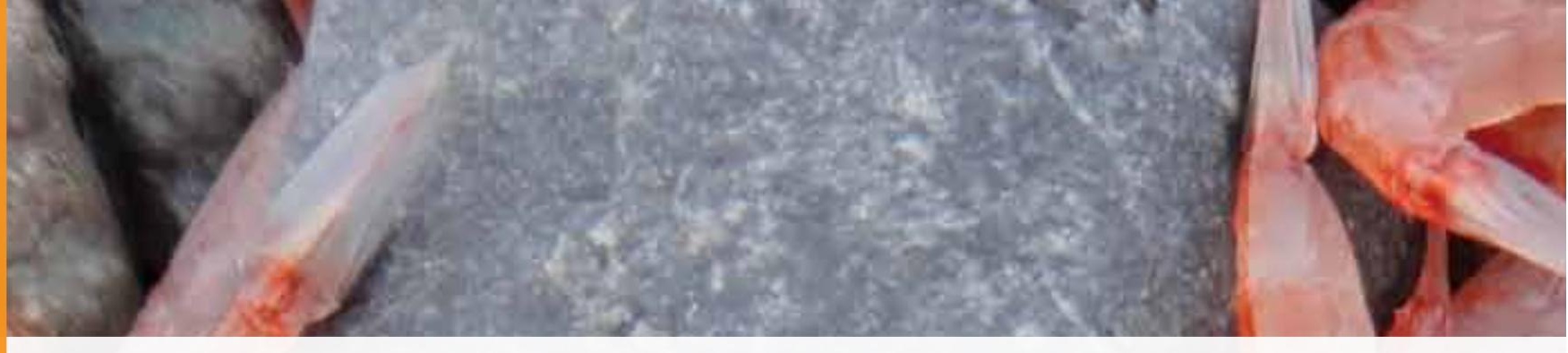

DOI: http://dx.doi.org/10.4322/apa.2015.022

\title{
CHARACTERISATION OF ANTARCTIC FISH OTOLITHS SAGITTAE FROM THE Notothenia rossii AND Notothenia coriiceps OF ADMIRALTY BAY
}

\author{
Tânia Zaleski, Mariana Forgati, Bruna Aline dos Santos Souza, Flavia Sant’Anna Rios \& Lucélia Donatti*
}

Laboratório de Biologia Adaptativa - Departamento de Biologia Celular -Universidade Federal do Paraná. R. Cel. Francisco Heráclito dos Santos, 210, Jardim das Américas, Curitiba - PR, 81531-970, Brazil

*e-mail: donatti@ufpr.br

\begin{abstract}
The aim of this study is to characterize the otoliths sagittae of notothenioid fishes Notothenia rossii and Notothenia coriiceps, identifying morphological aspects, important for understanding the biology of species and their conservation. The otoliths of both species exhibit oval shaped, toothed margins, being more remarkable in N. coriiceps, characteristic of groundfish species associated with rocky or soft substrate. The rostrum and anti-rostrum are very evident. The otoliths of N. rossii are larger and heavier than those of $N$. coriiceps. The relationships between the standard length and the total length of the otolith growth indicates allometric positive $(b<1)$ in the two species, as observed for the perimeter to the area of the otoliths and the weight of the fish.
\end{abstract}

Keywords: Otolith Morphology, Notothenioids, Ecology

\section{Introduction}

Otoliths are acellular, calcareous concretions, constituted by calcium carbonate and other inorganic salts. Such structures develop on a protein matrix in the inner ear of vertebrates and teleost fish. Three pairs are to be found: sagittae, asterisci and lapilli. The sagitta is the most widely used bone structure for age and growth studies (Gaemers, 1984). These pair of otoliths consists of two concave elliptical bodies, constricted on the sides with its largest axis geared towards the anteroposterior direction of the animal, each sagitta is the mirror image of one another (Pannella, 1980). The morphology and morphometry of this pair of otoliths are utilised in the majority of trophic studies as well as in the identification of populations and species (Yefanov \& Khorevin, 1979). Thus, the morphological description of otoliths' both macro and microstructure have been carried out in many Antarctic fishes (Radtke \& Kellermann, 1991, Ruzicka \& Radtke, 1995, Avallone et al. 2003).

In this study, sagittae otoliths of Notothenia rossii and Notothenia coriiceps, both species of the family
Nototheniidae, have had their morphology described and associated with ecomorphological aspects.

\section{Materials and Methods}

Samples of Notothenia rossii and N. coriiceps were caught with hook and line in the Admiralty Bay, King George Island, South Shetlands Archipelago, Commandant Ferraz

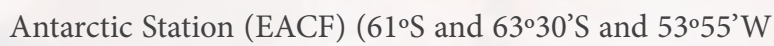
and $62^{\circ} 50^{\prime} \mathrm{W}$ ),

After capture, fishes were measured in their total length (TL) and standard length (SL), weighed and sex determined. Both right and left sagittae otoliths were removed, washed with distilled water and conserved in plastic tubes. Their shape, contour, form and position of the acoustic sulcus were available. The sagittae otoliths were measured in their total length (TLO), width (WO), perimeter $(\mathrm{PeO})$ and area (HO) through the programme Image J. The comparisons between species and between the right and left otoliths were carried out using the test $T$ de Student $(p<0.05)$. 


\section{Results}

In the study period, 160 otoliths from Notothenia rossii were extracted, with average length of 29.61 (20.5 - 35.5 $\mathrm{cm})$ and average weight of (100 - $585 \mathrm{~g})$, and 146 otoliths from $N$. coriiceps with average length of $36.6(22.5-47.0 \mathrm{~cm})$ and average weight of 718 (150-1580 g). For N. rossii, the growth of the right and left otoliths showed no significant difference $(p=0.07)$, as well as for $N$. coriiceps $(p=0.19)$. Thus, the right otolith of both same was utilised in the following procedures of analysis and was substituted by the left when necessary.

The otoliths of the two species showed oval shape, the length greater than the height. The upper profile is slightly convex and is more marked in N. rossii. The dorsal margin in $N$. rossii shows gentle irregularities, whereas such irregularities are more remarkable in $N$. coriiceps, with a quite jagged margin. The anterior margin is defined by the presence of the rostrum, which is more pointed in $N$. coriiceps and more rounded in N. rossii, which shows a more developed anterostrum. The acoustic sulcus in both analysed same is rectilinear regarding their orientation, different regarding their structure, being divided by the colo in the ostium and the tail. The ostium is opened in the anterior margin of the otolith in low relief, being the most concave portion of the acoustic sulcus (Figure 1).

The otoliths of the species $N$. coriiceps are bigger $(p<0.001)$ and heavier $(p<0.001)$ than those of the $N$. rossii. The ratio between the standard and total length of the otolith indicate a positive allometric growth $(b<1)$ in the two species, as well as ratios between standard length and the area of the otolith, which are represented by the equation $\mathrm{HO}=1.5 \mathrm{TL}+1.41 ; \mathrm{r}^{2}=0.32$ in the $N$. coriiceps; and $\mathrm{HO}=1.5 \mathrm{TL}+0.25 ; \mathrm{r}^{2}=0.43$ in the $N$. rossii.
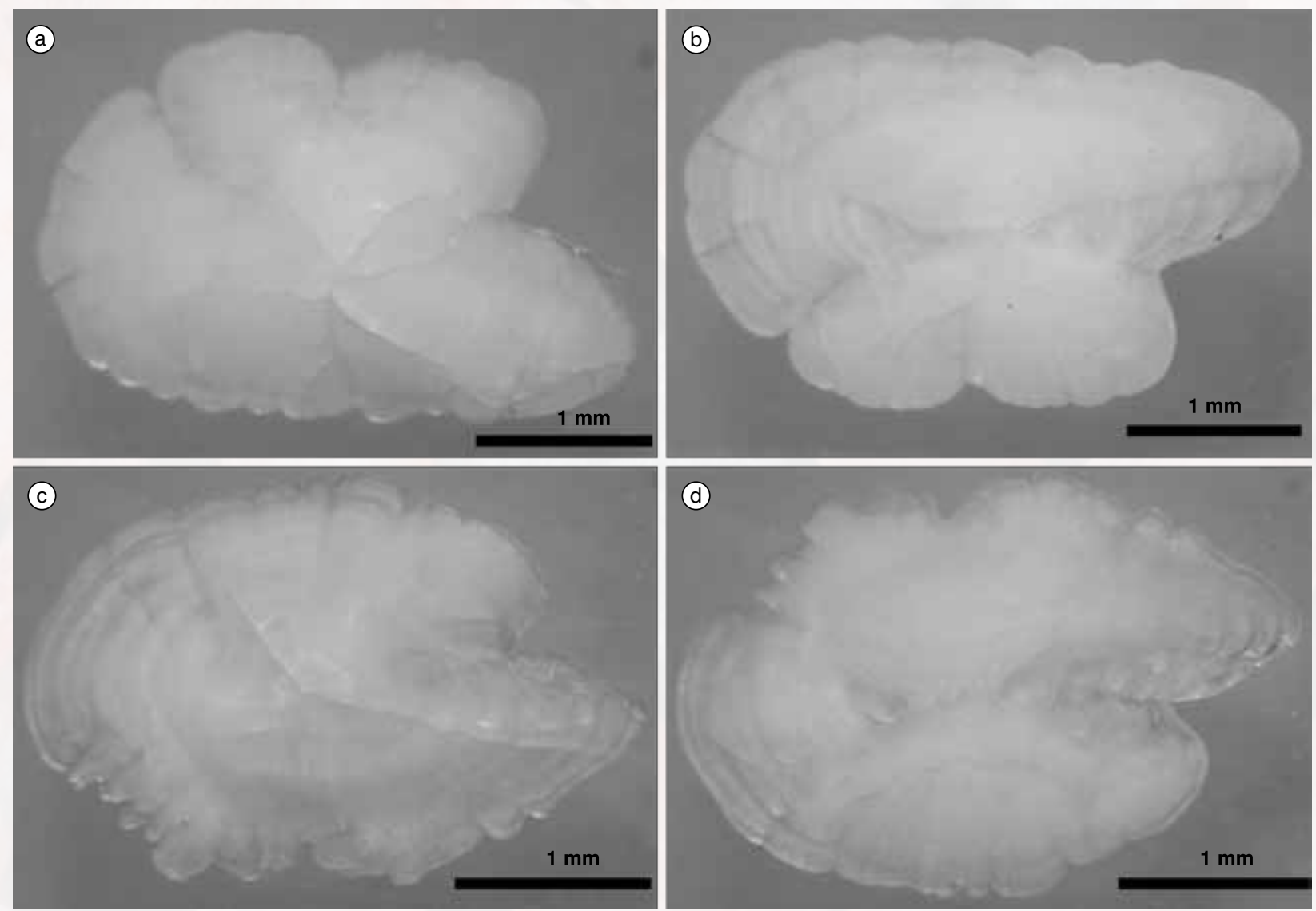

Figure 1. Sagittae otoliths (orientation posterior-anterior) of N. rossii (A and B) and N. coriiceps (C and D). A and C, dorsal view, B and D, ventral view. 


\section{Discussion}

The otoliths with an oval-rounded shape observed in $N$. rossii and $N$. coriiceps are characteristic of species with benthic habits (Volpedo \& Echeverría, 2003). The development of the rostrum may be associated with the type of substrate and the habitat of the organism. In the Admiralty Bay, the substrate is characterised by a complex topography and geomorphology (Siciński et al., 2011). It has a diverse coastal line, which provides for a vast variety of habitats, justifying the rostrum more pointed in $N$. coriiceps and more rounded in N. rossii observed in this work.

The absence of morphological descriptions of sagittae from the studied species makes it impossible to establish a comparison with populations from other regions. The diversity of shapes in the otoliths is firstly related to balance and orientation and secondly to hearing (Popper et al., 2005). Genetic and environmental factors, especially those concerning temperature, act in the formation of the otoliths' shape (Campana, 2005). In order to determine the age from the rigid structure in teleosts, a yearly deposition of the calcified tissues were generally used (Schulz-Mirbach et al., 2011). However, the absence of a distinct periodicity of the hydrographical conditions in Antarctic waters difficult the determining of the age from the reading of disposition rings (Schulz-Mirbach et al., 2011). Thus, techniques, which combine chemical and structural analysis of otoliths in Antarctic fishes will not only be able to generate more precise data on the influence of environmental parameters on the growth and status of the population, but also information on the hydrography and the nutritional state of the species.

\section{Conclusion}

Otoliths of N. rossii and N. coriiceps show an ovalrounded shape characteristic of fishes with benthic habits. The moderately developed rostrum is related to a variable substratum, which ranges from being soft to being rocky. The ratios of the fish's length and the area of the otolith indicate a positive allometric growth.

\section{Acknowledgements}

This work was integrates the National Institute of Science and Technology Antarctic Environmental Research (INCTAPA) that receives scientific and financial support from the National Council for Research and Development (CNPq process: $n^{\circ}$ 574018/2008-5) and Carlos Chagas Research Support Foundation of the State of Rio de Janeiro (FAPERJ $n^{\circ}$ E-16/170.023/2008). The authors also acknowledge the support of the Brazilian Ministries of Science, Technology and Innovation (MCTI), of Environment (MMA) and InterMinistry Commission for Sea Resources (CIRM).

\section{References}

Avallone, B., Balassone, G., Balsamo, G., Di Giacomo, G., Marmo, E., Casciello, M. G. et al. (2003). The otoliths of the Antarctic teleost Trematomus bernacchii: scanning electron microscopy and X-ray diffraction studies. Journal of Submicroscopic Cytology Pathology, 35, 69-76. PMid:12762654

Campana, S. E. (2005). Otolith science entering the 12st century. Marine and Freshwater Research, 56, 753-762. http://dx.doi. org/10.1071/MF04147

Gaemers, P. (1984). Taxonomic position of the Cichlidae (Pisces, Perciformes) as demonstrated by the morphology of their otoliths. Netherlands Journal of Zoology, 34(4), 566-595. http://dx.doi.org/10.1163/002829684X00290

Pannella, G. (1980). Growth patterns in fish sagittae. In D. C. Rhoads \& R. A. Lutz (Eds.), Skeletal growth of aquatic organisms: biological records of environmental change (pp. 519-560). New York: Plenum Press. http://dx.doi.org/10.1007/978-1-48994995-0_16

Popper, A. N., Ramcharitar, J., \& Campana, S. E. (2005). Why otoliths? Insights from inner ear physiology and fisheries biology. Marine and Freshwater Research, 56(5), 497-504. http://dx.doi.org/10.1071/MF04267 
Radtke, R. L., \& Kellermann, A. (1991). Microstructural analysis of growth patterns in the early life history of Antarctic fishes. In G. DiPrisco, B. Maresca \& B. Tota (Eds.), Biology of Antarctic fish (pp. 101-115). Berlin: Springer Verlag. http://dx.doi. org/10.1007/978-3-642-76217-8_7

Ruzicka, J. J., \& Radtke, R. L. (1995). Estimating the age of Antarctic larval fish from otolith microstrucutre using light and electron microscopy. Polar Biology, 15(8), 587-592. http://dx.doi.org/10.1007/BF00239651

Siciński, J., Jażdżewski, K., Debroyer, C., Presler, P., Ligowski, R., Nonato, E. F. et al. (2011). Admiralty Bay Benthos diversity: a census of a complex polar ecosystem. Deep Sea Research II, 58(1-2), 30-48. http://dx.doi.org/10.1016/j.dsr2.2010.09.005

Schulz-Mirbach, T., Riesch, R., García de Leon, F. J., \& Plath, M. (2011). Effects of extreme habitat conditions on otolith morphology: a case study on extremophile live bearing fishes (Poecilia mexicana, P. sulphuraria). Zoology, 114(6), 321-334. PMid:22000528. http://dx.doi.org/10.1016/j.zool.2011.07.004

Volpedo, A., \& Echeverria, D. D. (2003). Ecomorphological patterns of the sagitta in fish on the continental shelf off Argentine. Fisheries Research, 60(2-3), 551-560. http://dx.doi.org/10.1016/S0165-7836(02)00170-4

Yefanov, V. N., \& Khorevin, L. O. (1979). Distinguishing populations of pink salmon Oncorhynchus gorbuxha, by the size of their otoliths. Journal of Ichthyology, 19, 142-145.

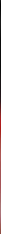

